\title{
CSIRO attacked over review's 'omissions'
}

Sydney. The staff of Australia's largest research body, the Commonwealth Scientific and Industrial Research Organization (CSIRO), have launched an unprecedented attack on the board following the publication of an internal review last month that, they say, fails to address important issues.

A statement signed by more than a hundred CSIRO employees says there is a "widespread lack of confidence" in both the board and the committee - consisting primarily of board members - that produced the internal report.

Problems cited include the fact that the internal report failed to mention either communication problems within the organization or that scientific excellence was one of the organization's goals. The report is also said to have omitted any discussion of the need to restructure the board itself.

Roy Green, acting chief executive of CSIRO, has responded by promising that a "representative committee" will be set up to review internal communications and identify time-wasting procedures that could be abolished. But he has rejected the suggestion that the committee had not considered scientific excellence in its review.

A spokesman for CSIRO, which has an annual budget of $\mathrm{A} \$ 662$ million (US $\$ 490$ million), said last week that the new committee would be similar to those often estab- lished by the organization, but that no members have yet been named.

CSIRO's present problems stem partly from the adoption of a new management structure in 1986, under which the organization's basic operating units - known as divisions - were grouped into six 'institutes' of broadly similar research areas. Although this was meant to create synergy between researchers in related fields, the institute became directly involved in assessing the quality and effectiveness of the research carried out in the divisions.

Last year, a Senate committee report on the organization pointed out that the institutes generated "a vast amount of paperwork without clear and worthwhile objectives" (see Nature 372, 585; 1994). The committee also criticized the organization's board, chaired by Adrienne Clarke, professor of molecular biology at Melbourne University, for neglecting the employment conditions and morale of its staff, as well as the response of John Stocker, CSIRO's former chief executive, to the problems it had raised. Stocker left the organization at the end of his five-year term in March.

In response, CSIRO released in midApril the conclusions of an internal review that broadly recommended abolishing the institutes and suggested a return to the old structure of divisions reporting direct to

\section{Solar craft reaches for new heights}

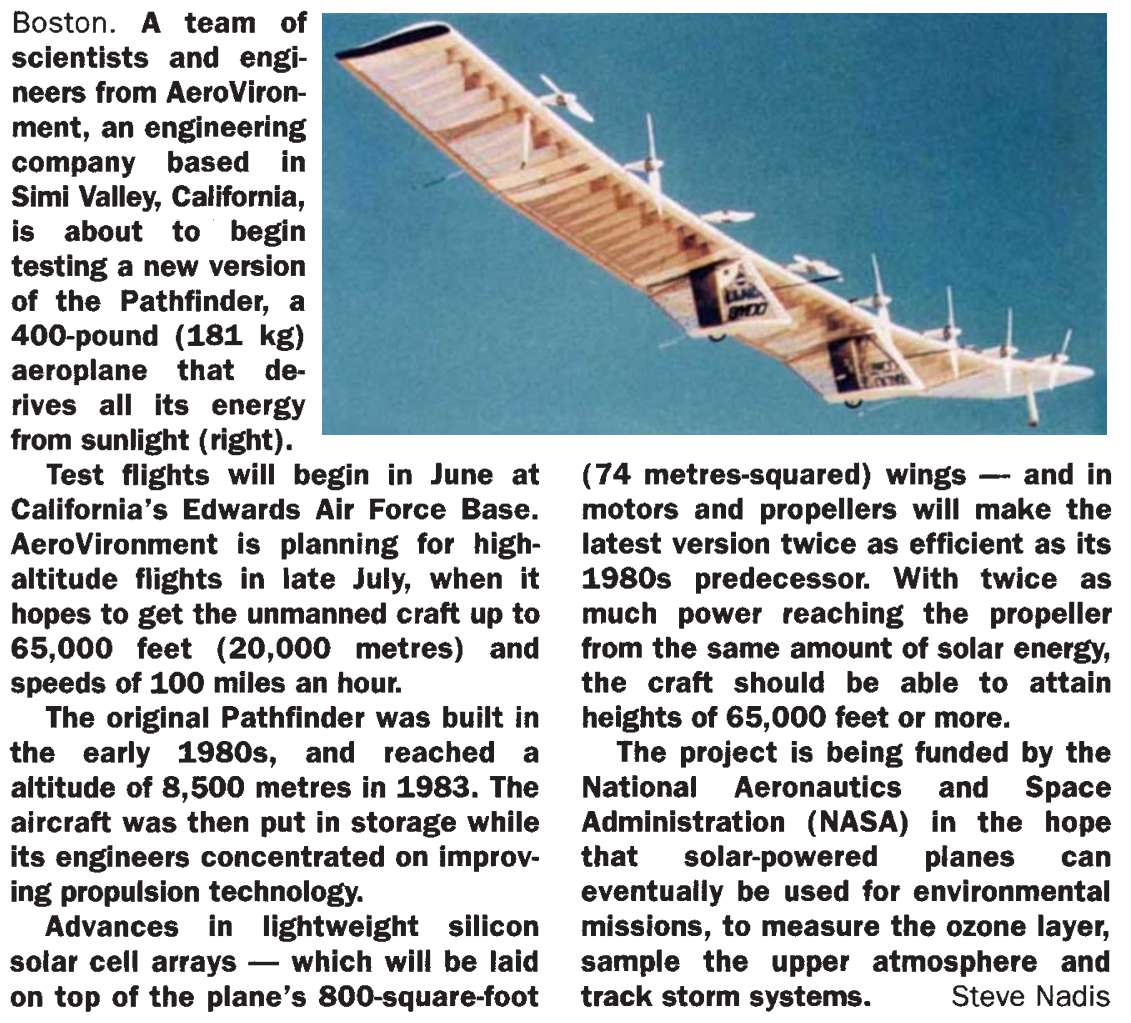

head office (see Nature 374, 587; 1995).

At the time, Green denied that the review's recommendations were connected with the Senate report, and said that the institute structure had worked well, even if it was no longer appropriate. He also commented that any major changes would have to await the appointment of the new chief executive officer.

CSIRO staff are certainly anxious to see change. Peter O'Donohue, general secretary of the CSIRO Division of the Commonwealth Public Service Union, agrees that there is widespread support for the proposal that the institutes be abolished. But he emphasizes that it does not represent union policy, which is currently being thrashed out.

Mark Lawson

\section{A modest boost for Australian science}

Sydney. Australia's two major grant-giving bodies are the main beneficiaries of a slight increase in overall funding for science in the national budget announced last week.

Funding for research through the Australian Research Council is being increased by 9 per cent in real terms to $A \$ 350.2$ million (US $\$ 260$ million). Some of the extra money, however, has been earmarked for higher education. The National Health and Medical Research Council (NH\&MRC) will have its allocation increased by 7 per cent to A $\$ 139.2$ million.

According to a 'Science and Technology Budget Statement' released the day after the main budget, the losers include rural research and development, which will fall by 6 per cent to $\$ 130$ million, and "other $R \& D$ agencies", whose funding will drop by 5 per cent to A $\$ 232.2$ million. Overall, however, the total federal spending on science next year will grow by 0.7 per cent to around A $\$ 3.6$ billion.

The statement contained some disappointments for researchers. In particular, although the NH\&MRC's budget was increased - and despite some intense lobbying during the budget process - the new money is far from the extra $A \$ 200$ million a year which medical researchers believed they had been promised during the last federal election campaign.

Also, statistics presented in the budget statement show that Australian business spending on $R \& D$ is still much less than that of many other industrialized nations, falling as a percentage of gross national product below Italy and just above Ireland. One reason is that Australia's economy is still based largely on the mining industry, which tends to spend money on geological exploration rather than research.

M. L.

See also: pages 177 to 182 . 